\title{
Niemann-Pick disease type A
}

INSERM

\section{Source}

INSERM. (1999). Orphanet: an online rare disease and orphan drug data base. NiemannPick disease type A. ORPHA:77292

Niemann-Pick disease type $A$ is a very severe subtype of Niemann-Pick disease, an autosomal recessive lysosomal disease, and is characterized clinically by onset in infancy or early childhood with failure to thrive, hepatosplenomegaly, and rapidly progressive neurodegenerative disorders. 